\begin{tabular}{|c|c|c|c|c|c|c|c|c|c|}
\hline & SEARCH ) & & & & DONATE & HELP & CONTACT AHA & SIGN IN & HOME \\
\hline ADVANCED & $S E A R C H$ & & & & & & & & \\
\hline Feedback & Subscriptions & Archives & Search & $\begin{array}{c}\text { Table of } \\
\text { Contents }\end{array}$ & & & & & \\
\hline
\end{tabular}

American Heart Association。

Learn and Live

\title{
Circulation
}

This Article

Abstract FREE

- Alert me when this article is cited

- Alert me if a correction is posted

- Citation Map

\section{Altered Tissue Degradation and Distribution of Atrial Natriuretic Peptide in Patients With Idiopathic Dilated Cardiomyopathy and Its Relationship With Clinical Severity of the Disease and Sodium Handling}

Giorgio Iervasi, MD; Aldo Clerico, MD; Sergio Berti, MD; Alessandro Pilo; Andrea Biagini, MD; Romano Bianchi, MD; Luigi Donato, MD

From the CNR Institute of Clinical Physiology, Pisa, Italy.
Services

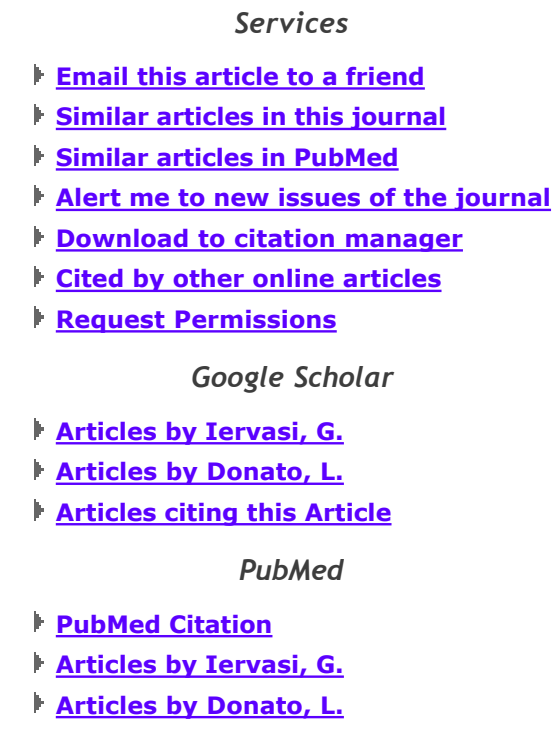

\section{$\rightarrow$ Abstract}

Background Atrial natriuretic peptide (ANP) has been suggested to play an important role in heart failure, preserving cardiorenal homeostasis through maintenance of the sodium balance and inhibition of the detrimental effects of the neurohormonal vasoconstrictor system. The current study was designed to investigate whether there is a disturbed renewal and distribution of ANP in patients with idiopathic dilated cardiomyopathy (IDC) with differing clinical severity of disease.

- Top
$=$ Abstract
$>$ Introduction
$\nabla$ Experimental Subjects
$>\underline{\text { Control Group }}$
$\nabla \underline{\text { Methods }}$
$\nabla \underline{\text { Discussion }}$
$\nabla \underline{\text { References }}$

$\Delta \underline{\text { Top }}$

Experimental Subjects

References

Methods and Results We used a tracer method to perform a cross-sectional study of 15 IDC patients with differing clinical severity (New York Heart Association functional class I to III), prospectively divided into two groups according to their functional class (group 1, classes I and II; group 2, classes II-III and III). Eleven normotensive, nonobese male volunteers also were studied as a control group. Main ANP kinetic parameters were derived from the disappearance curve of the labeled hormone after the bolus injection of $\left[{ }^{125} \mathrm{I}\right]$-labeled ANP. A high-performance liquid chromatography technique was used to separate the radiolabeled hormone in each plasma sample. Patients in group 1 showed higher ANP metabolic clearance rate (MCR) $\left(2731.9 \pm 726.2 \mathrm{~mL} \cdot \mathrm{min}^{-1} \cdot \mathrm{m}^{-2}\right)$ than patients of group $2\left(1718.4 \pm 621.2 \mathrm{~mL} \cdot \mathrm{min}^{-1} \cdot \mathrm{m}^{-2}\right)$ and control subjects $\left(1873.1 \pm 551.2 \mathrm{~mL} \cdot \mathrm{min}^{-1} \cdot \mathrm{m}^{-2}\right)$. ANP disposal (MCR) positively correlated with biological hormonal effect (urinary sodium excretion) both in control subjects and in patients. In IDC patients of both groups, however, MCR values were always higher (approximately doubled) than the values found in control subjects at the corresponding sodium excretion. This finding indicates that a reduced ANP biological activity is associated with hormone degradation in patients. Moreover, patients of group 2 showed significantly higher ANP production rates $\left(395.6 \pm 183.8 \mathrm{ng} \cdot \mathrm{min}^{-1} \cdot \mathrm{m}^{-2}\right)$ 
than group $1\left(166.0 \pm 139.0 \mathrm{ng} \cdot \mathrm{min}^{-1} \cdot \mathrm{m}^{-2}\right)$ and control subjects $\left(130.7 \pm 105.4 \mathrm{ng} \cdot \mathrm{min}^{-1} \cdot \mathrm{m}^{-2}\right)$ despite a marked reduction in sodium excretion. Patients with IDC showed a progressive reduction in the total distribution volume (group 1, 19.8 $\pm 5.8 \mathrm{~L} / \mathrm{m}^{2}$; group 2, $12.7 \pm 6.9 \mathrm{~L} / \mathrm{m}^{2}$; control subjects, $27.0 \pm 11.6 \mathrm{~L} / \mathrm{m}^{2}$ ) of the hormone; this probably was due to a reduction in exchanges of ANP with peripheral tissues.

Conclusions Our study demonstrates a markedly altered degradation and distribution of ANP in patients with IDC, even in those at the early stage of clinical disease (classes I and II, group 1) who have ANP plasma levels in the normal range.

Key Words: atrial natriuretic factor $\bullet$ cardiomyopathy $\bullet$ metabolism $\bullet$ peptides

\section{$\rightarrow \quad$ Introduction}

In recent years, it has been postulated that patients with idiopathic dilated cardiomyopathy (IDC) may develop heart failure not only as a result of primary deficiency of cardiac contractility but also as a result of an alteration of peripheral mechanisms responsible for regulation of vascular contractility and of fluid and electrolyte homeostasis. $\stackrel{1}{2}$ Sodium and water retention, which are the principal clinical characteristics of congestive heart failure, are caused mainly by the activation of neurohormonal vasoconstrictor systems (including the renin-angiotensin-aldosterone system, the arginine-vasopressin system, and sympathetic nervous system). $\underline{3} \underline{4} \underline{5}$

Since atrial natriuretic peptide (ANP) has natriuretic and vasodilator effects and inhibits the renin-angiotensin-aldosterone, arginine-vasopressin, and sympathetic nervous systems, it was suggested to play an important role in asymptomatic left ventricular dysfunction by preserving cardiorenal homeostasis through maintenance of the sodium balance and inhibition of the detrimental effects of the neurohormonal vasoconstrictor system. $\underline{2} \underline{3} \underline{5}$

At present, this hypothesis is supported only by indirect observations. In fact, the hypothetical role of ANP in heart failure has generally been investigated by measuring the circulating levels of the hormone. $\underline{6} \underline{7} \underline{8} \underline{9} \underline{10} \underline{11} \underline{12}$ However, in a previous kinetic study (see Reference 22), the first one performed in humans under steady-state conditions using a tracer method, we demonstrated that ANP plasma levels could not be considered a reliable estimate of the amount of hormone produced by the heart and still less of the activity of the overall ANP system (as, on the contrary, it was assumed a priori in several physiological and clinical studies in which only the ANP circulating levels were measured) because (1) the plasma pool of the hormone is only $1 / 15$ to $1 / 20$ of the total body pool, and (2) the plasma half-life of ANP is very short (only a few minutes). Indeed, the plasma levels of ANP closely parallel the instantaneous secretion rate, and it is therefore likely that they may greatly fluctuate during a 24-hour period in response to different pathophysiological stimuli.

On the other hand, it is conceivable that the metabolic clearance rate (when measured under steady-state conditions) may represent a reliable estimate of the potential uptake and degradation rate of ANP by the periphery and, consequently, of the overall hormonal activity, because it reflects the functional state of the overall systems (such as receptors and degradation enzymes), which require hours or even days for their modulation. In previous studies on ANP kinetics, high doses of the peptide were administered, greatly increasing ANP circulating levels and thereby inducing a major perturbation of the hormone kinetics; consequently, these studies were performed under a non-steady-state condition. $\underline{12} \underline{13} \underline{14} \underline{15} \underline{16} \underline{17} \underline{18} \underline{19} \underline{20} \underline{21}$ These techniques are not suitable for the detection of the fine interrelations between ANP and the other neurohormonal systems in basal and/or pathophysiological conditions.

In the present report, we used the previously described tracer method $\underline{22}$ to perform a cross-sectional study of 15 IDC patients subdivided into two groups according to their differing clinical severity of disease (New York Heart 
Association functional class) in order to investigate the relations between ANP distribution and removal and sodium handling. Eleven normotensive, nonobese male volunteers also were studied as a control group.

\section{Experimental Subjects}

\section{Patients}

Fifteen patients (age, 23 to 59 years) with IDC and normal arterial blood pressure (mean systolic blood pressure, $124 \pm 13 \mathrm{~mm} \mathrm{Hg}$; mean diastolic blood pressure, $78 \pm 8$ $\mathrm{mm} \mathrm{Hg}$ ) were enrolled in the study; their main clinical parameters are reported in Table 1⿴囗十 Patients were prospectively divided into two groups according to their functional class: the first group comprised 7 patients (patients 1 through 7) with less severe symptoms of disease, who were in class I or II, while the second one consisted of 8

\begin{tabular}{|l}
\hline Top \\
- Abstract \\
- Introduction \\
$>$ Experimental Subjects \\
$>$ Control Group \\
$>$ Rethods \\
$>$ Desults \\
$>$ References \\
\hline
\end{tabular}
patients (patients 8 through 15) with more severe symptoms, who were in classes II-III or III.

View this table: Table 1. Cardiac Index, Ejection Fraction, Pulmonary Wedge Pressure, Right Atrial [in this window] Chamber Dimensions, Left Atrial Chamber Dimensions, Right Atrial Pressure, and [in a new window] NYHA Class of Patients

Patients of group 1 were treated only with a relative restriction of both physical activity and sodium intake (using a personalized, well-controlled diet); pharmacological treatment with vasodilators (generally an ACE inhibitor) and diuretics (generally a loop diuretic) was added for patients of group 2. Because it is well known that several drugs can affect ANP metabolism, we decided to stop all the drugs (that is, ACE inhibitors and diuretics) 3 days before admittance to the metabolic ward. For the same reasons, patients with congestive heart failure (such as some patients in classes III and IV) being treated with drugs with a relatively long half-life (such as digitalis drugs) were not included in the study. Moreover, patients with atrial fibrillation or other arrhythmias, which can affect the secretion and metabolism of ANP, $\underline{23}$ were also excluded from the study.

In all patients, a thorough clinical history and physical examination, two-dimensional color Doppler echocardiography, ${ }^{201} \mathrm{Tl}$ stress scan, coronary angiography, and left ventriculography were performed in order to exclude any ischemic, valvular, hypertensive, or other forms of secondary cardiomyopathy. All patients also underwent further biohumoral tests to exclude metabolic, rheumatologic, autoimmune, or viral disorders. The presence of arrhythmias was evaluated by 48-hour Holter monitoring. Myocardial contractility, dimensions, and function were assessed by two-dimensional echocardiography, radionuclide ventriculography, and hemodynamic study.

All patients had normal renal function as judged from their serum creatinine levels and creatinine clearance rates. In the patients of group 2, normal renal function was confirmed by measurement of the glomerular filtration rate and effective renal plasma flow using classic nuclear medicine techniques.

The patients were hospitalized in the metabolic ward of our institute for the time necessary to perform the kinetic studies. At entrance, all patients were following a strictly controlled sodium intake diet; the mean intrapatient and between-patient variability (coefficient of variation, CV) in sodium intake (as evaluated by an expert dietician through daily interviews as well as by the clinicians, who measured daily urinary sodium excretion) was less than $10 \%$, thus reflecting the variability in food composition and differences in the amount of food consumed daily by the patients. Body weight, plasma and urinary creatinine, and electrolytes were measured daily; to ensure that a sodium balance was being achieved, urine collections were promptly analyzed for volume and electrolyte excretion. The ANP turnover study was performed only after three consecutive 24-hour urinary collections demonstrating the achievement of a steady state of sodium excretion. 
A relatively wide range of sodium intakes was investigated (see Table 2匹): 10 patients (patients 1 through 4, 8 through 12, and 15) were studied at a relatively restricted sodium intake; 2 patients (patients 5 and 13) were studied at a low sodium intake; 2 patients (patients 6 and 14) were studied twice at different sodium intakes: patient 6 was studied at a relatively high (study 6a) and, 1 month later, at a low sodium intake (study 6b); patient 14 was first studied at restricted sodium intake (study 14a) and, 1 month later, at a low sodium intake (study 14b); patient 7 was studied twice at the same sodium intake $(110 \mathrm{mmol} / \mathrm{d})$ with a 7 -day interval between the two studies (studies $7 \mathrm{a}$ and $7 b)$ to evaluate the reproducibility of the tracer method.

View this table: Table 2. Plasma Concentrations of ANP, PRA, and Aldosterone and 24-Hour Urinary [in this window] Sodium Excretion in Control Subjects and Patients in a new window]

In 16 studies, a steady state of sodium excretion was achieved with an amount of sodium daily assumed equal to that excreted by the kidney; in only two patients with more severe disease (patients 8 and 9) was the sodium intake (on average, $120 \mathrm{mmol} / \mathrm{d}$ ) higher than the ability of their kidneys to excrete sodium, and consequently sodium retention was observed.

\section{Control Group}

Eleven normotensive, nonobese male volunteers (age, 26 to 54 years) from our medical and nursing staff served as the control group. These subjects were studied at variable sodium intakes using the same protocol previously described $\frac{22}{2}$ in the present study, their hormonal and kinetic data are reported for comparison with those obtained in patients. Hemodynamic parameters in the control group were not evaluated for ethical reasons. All subjects were completely free from cardiac symptoms and myocardial function, as assessed by two-dimensional echocardiography, was completely normal.

- Top

Abstract

- Introduction

- Experimental Subjects

- Control Group

$\checkmark$ Methods

$\nabla$ Results

$\checkmark$ Discussion

$\checkmark$ References

Informed consent was obtained from all subjects studied, and the protocol was approved by the local ethics committee. All participants received a daily dose of 20 drops of saturated Lugol solution from the day before until the day after the kinetic study.

\section{$>\quad$ Methods}

\section{Preparation of the Tracer}

Synthetic $a$ - ${ }_{1-28}$ ANP (Bachem Feinchemikalien AG) was iodinated with $\mathrm{Na}^{125} \mathrm{I}$ or $\mathrm{Na}$ ${ }^{131}$ I (both supplied by Sorin) by means of a lactoperoxidase technique the day before the kinetic study, as previously described. $\underline{22}$ The labeling mixture then was purified using both ion exchange chromatography and high-performance liquid chromatography (HPLC) procedures. $\frac{22}{}$ Because only the fraction containing the monoiodinated labeled peptide was used to prepare the tracer, the specific activity of [ $\left.{ }^{125} \mathrm{I}\right] \mathrm{ANP}$ ranged

- Top

- Abstract

- Introduction

- Experimental Subjects

- Control Group

- Methods

$\checkmark$ Results

$\checkmark$ Discussion

References between 2000 and $2200 \mathrm{Ci} / \mathrm{mmol}(650$ to $700 \mu \mathrm{Ci} / \mu \mathrm{g})$, that is, a value very close to the theoretical maximum specific activity for the monoradioiodinated hormone $(2200 \mathrm{Ci} / \mathrm{mmol})$.

\section{Experimental Protocol}

On the day after labeling, (9 to $10 \mathrm{AM}$ ), the HPLC fraction containing the monoiodinated $\left[{ }^{125} \mathrm{I}\right] \mathrm{ANP}$ was loaded onto a DEAE Sephadex column and eluted with phosphate buffer, $\mathrm{pH} 7.4,0.05 \mathrm{~mol} / \mathrm{L}$, in polypropylene tubes containing $0.5 \mathrm{~mL}$ of a $4 \%$ human albumin solution; the purified tracer then was sterilized with a $0.22-\mu \mathrm{m}$ filter (Millipore, Waters Associates) immediately before the injection. 
Each subject was kept at rest in a clinostatic position for at least 30 minutes, and an automatic blood pressure recorder and electrodes were positioned for continuous ECG and blood pressure monitoring throughout the study.

A known amount (about $80 \mu \mathrm{Ci}$ ) of freshly prepared tracer (corresponding to about $100 \mathrm{ng}$ of $\left[{ }^{125} \mathrm{I}\right] \mathrm{ANP}$ ) was intravenously bolus injected, and 13 to 15 venous blood samples then were collected before and during the 40 minutes after injection (at 1.5 and 2.15 minutes, then about every minute for 5 minutes, every 2 minutes from 8 to 16 minutes, and finally every 5 to 10 minutes). A volume of $0.9 \% \mathrm{NaCl}$ solution equal to the volume (typically about $100 \mathrm{~mL}$ ) of blood withdrawn was infused through the three-way stopcock during the study.

The blood samples collected were immediately put into ice-chilled disposable polypropylene tubes containing aprotinin $(500 \mathrm{KIU} / \mathrm{mL}$ of plasma) and EDTA $(1 \mathrm{mg} / \mathrm{mL}$ of plasma), and the plasma then was separated in a refrigerated centrifuge within 1 hour.

\section{Determination of $\left[{ }^{125} \mathrm{I}\right]$ ANP Recovery Using $\left[{ }^{131} \mathrm{I}\right]$ ANP as Internal Standard}

During the kinetic study, the exchange chromatographic fraction of $\left[{ }^{131} \mathrm{I}\right] \mathrm{ANP}$, prepared the day before and stored at $-20^{\circ} \mathrm{C}$, was purified by HPLC as described for $\left[{ }^{125} \mathrm{I}\right] \mathrm{ANP} . \underline{22}$ To determine the recovery of labeled ANP throughout the extraction and purification procedures, a known amount of purified [ $\left.{ }^{131} \mathrm{I}\right] \mathrm{ANP}$ (about 3000 to 4000 $\mathrm{cpm}$ ) was added to each plasma sample immediately after the blood separation by centrifugation, as previously described. $\underline{22}$

\section{Extraction and Purification of Plasma-Labeled ANP and Metabolites by HPLC}

Three-milliliter plasma samples were loaded onto Bond Elut C-18 cartridges (Analytical International) activated with $2 \mathrm{~mL}$ of methanol and washed with $4 \mathrm{~mL}$ of $1 \%$ TFA. After a $10-\mathrm{mL}$ washout with $0.1 \%$ TFA, labeled peptides were eluted with $3 \mathrm{~mL}$ of a solution containing methanol/TFA 99:1. The collected effluent was evaporated using a vacuum centrifuge, and the samples were reconstituted with $60 \mu \mathrm{L}$ of $0.1 \%$ acetic acid and after $0.45-\mu \mathrm{m}$ filtration were subjected to HPLC. $\underline{22}$

\section{Gamma Counting}

The ${ }^{125}$ I and ${ }^{131}$ I activities were measured in a gamma counter (1282 CompuGamma CS, LKB Wallac) with an efficiency of 54\% and $60 \%$, respectively; the counting time was 20 minutes for each fraction, and the operating conditions were chosen to obtain a high (sample) ${ }^{2}$-to-background ratio. After background subtraction, the measured ${ }^{125}$ I counts were corrected for ${ }^{131}$ I spillover into the ${ }^{125}$ I channel (which was $6 \%$ under the chosen conditions).

\section{Assay Methods}

For the ANP assay, blood samples (two 8- to 10-mL samples) were collected just before the injection of the tracer (-15 minutes and 0 time) into ice-chilled disposable polypropylene tubes containing aprotinin $(500 \mathrm{KIU} / \mathrm{mL}$ of plasma) and EDTA ( $1 \mathrm{mg} / \mathrm{mL}$ of plasma). They were immediately separated by centrifugation and were then frozen and stored in various aliquots at $-70^{\circ} \mathrm{C}$ until assayed.

Plasma ANP concentrations were measured by using a radioimmunoassay (RIA) kit (RIA for $\alpha$-human ANP, Peninsula Laboratories, Inc), following the manufacturer's instructions with some modifications. $\underline{24} \underline{25}$ The analytical performance and characteristics of this RIA were described in detail previously $\underline{24} \underline{25}$; in particular, the between-assay imprecision tested in several plasma pools with different ANP concentrations (range, 15 to 600 $\mathrm{pg} / \mathrm{mL}$ ) after extraction with Sep-Pak cartridges ranged between $15 \%$ and $45 \% \mathrm{CV}$. To increase assay precision, plasma samples were extracted in duplicate, and each plasma extract also was assayed in duplicate by RIA; moreover, the plasma samples with lower ANP concentrations were repeatedly measured in different runs of assays using different volumes of plasma extracts (from 2 to $4 \mathrm{~mL}$ ). The recovery of the Sep-Pak C-18 extraction was calculated by adding, before extraction, a known amount of [ $\left.{ }^{131} \mathrm{I}\right] \mathrm{ANP}$ to each sample assayed; the values obtained by RIA were corrected by extraction recovery (mean recovery, 65\%).

In three cases, the plasma ANP also was measured with a direct (without extraction) RIA kit (HANP-KIT-CISD, CIS diagnostic K.K., 26-19, Nishi-Ikeburo 5-Chome, Toshima-Ku) in the plasma samples collected during the 
kinetic study to verify whether circulating levels of the peptide hormone varied throughout the study. This RIA was used because it required only $100 \mu \mathrm{L}$ of plasma to perform the assay, thus allowing the determination (at least in duplicate) of ANP concentration in the residues (about 0.5 to $1 \mathrm{~mL}$ ) of experimental samples (collected during the kinetic study) after HPLC analysis. Plasma ANP concentrations were measured with this RIA kit, following the manufacturer's instructions. The between-assay imprecision of the direct ANP assay was better (CV ranging from $8 \%$ to $16 \%$ ) than that of RIA using a preliminary plasma extraction.

\section{Other Assay Methods}

Plasma renin activity (PRA) and plasma aldosterone were measured by RIA kits (supplied by Sorin Biomedica, Saluggia), following the manufacturer's instructions. Urine electrolytes were measured by using an automated system (ASTRA, Beckman).

\section{Data Analysis}

The mathematical analysis of the plasma disappearance curve of ANP was described in detail in a previous study. $\frac{22}{}$ A brief summary of the formulas used to compute the kinetic parameters addressed in the present study is reported. The experimental data were optimally fitted for all subjects by a sum of two exponentials $\left(\mathrm{P}(\mathrm{t})=\mathrm{A}_{1} \mathrm{e}^{\lambda}\right.$ $1^{\mathrm{t}}+\mathrm{A}_{2} \mathrm{e}^{\lambda} 2^{\mathrm{t}}, \lambda_{1}<\lambda_{2}<0$ ), using a weighted least-squares method. The area (AUC), first order moment (AUMC), and zero-time intercept $(\mathrm{P}(0))$ were calculated $\underline{27}$ from the coefficients $\mathrm{A}_{\mathrm{i}}\left(\%\right.$ dose/liter) and exponents $\lambda_{\mathrm{i}}\left(\mathrm{min}^{-1}\right)$ as follows:

$$
\begin{gathered}
A U C=\int_{0}^{\infty} P(t) d t=-\left(A_{1} / \lambda_{1}+A_{2} / \lambda_{2}\right) \\
A U M C=\int_{0}^{\infty} t P(t) d t=A_{1} / \lambda_{1}^{2}+A_{2} / \lambda_{2}^{2} \\
P(0)=A_{1}+A_{2}
\end{gathered}
$$

The following kinetic parameters were computed without assuming a definite model structure (compartmental or noncompartmental): (1) metabolic clearance rate, $\mathrm{MCR}=100 / \mathrm{AUC}(\mathrm{L} / \mathrm{min})$, and (2) initial distribution volume, $\mathrm{IDV}=100 / \mathrm{P}(0)$ (liters); IDV, computed according to the isotopic dilution principle, is the volume (plasma equivalent) of the initial distribution space where the circulating ANP rapidly equilibrates after entering in the blood stream: it includes, besides plasma volume itself, the sites of initial ( 2 to 3 minutes) reversible and irreversible uptake of the hormone. It is likely that, for substances that are very rapidly removed such as ANP, the degradation occurring in the first minutes after tracer injection can induce an increase in the estimated value of IDV.

Two additional kinetic parameters were obtained by using the noncompartmental approach, that is, assuming that all ANP degradation took place in the sampling pool: (1) mean residence time in the body, $\mathrm{MRTB}=\mathrm{AUMC} / \mathrm{AUC}$, and (2) total (plasma equivalent) distribution volume, $\mathrm{TDV}=\mathrm{MCR} \times \mathrm{MRTB}=100 \mathrm{xAUMC} /(\mathrm{AUC})^{2}$ (liters).

It is worth noting that both IDV and TDV are "plasma equivalent" volumes and do not directly correspond to true physical (or physiological) volumes; these two distribution parameters may be found to be greater than actual body volumes (for example, plasma volume, extracellular volume, or cellular volume) due to the possibly increased ANP concentration in some tissue compartments as compared with that measured in plasma. 
Peripheral (plasma equivalent) distribution volume (PDV) can be computed from the difference between total and initial distribution volume values, PDV=TDV-IDV (liters).

When the renewal parameter MCR is multiplied by the plasma concentration of cold ANP, an estimate of the amount of hormone degraded per unit time (disposal rate) is obtained; under steady-state conditions, the disposal rate also estimates the amount of ANP produced per time unit (production rate, PR).

\section{Statistical Analysis}

The statistical analysis was carried out by a Macintosh IIsi personal computer using the STATVIEW 4.0 and SUPERANOVA programs (Abacus Concepts, Inc). The data for the three independent groups (groups 1 and 2 of patients and control subjects) were analyzed by ANOVA, and the significant differences between the pairs of means were tested by the Scheffé's test. The Scheffé's test was chosen for multiple comparisons because it is generally considered one of the most conservative tests and also because it is very robust to violations of the assumptions typically associated with multiple comparison procedures (including heterogeneous variances). The results are expressed as mean $\pm \mathrm{SD}$.

\section{$>\quad$ Results}

\section{Hormone Concentrations}

The basal plasma levels of ANP and PRA found in our IDC patients and in the control subjects at the beginning of the kinetic study are reported in Table 2ד.

ANP levels were on average in the normal range in the patients of group 1 and were significantly increased (ANOVA, $P<.0004$ ) in the patients of group 2 (group 1 versus group 2, $P<.0025$; group 2 versus control subjects, $P<.0015$ ). ANP levels were weakly

- Top

- Abstract

Introduction

Experimental Subjects

- Control Group

- Methods

- Results

$\checkmark$ Discussion

References and negatively correlated with urinary sodium excretion values $(r=-.521, P=.0268, \mathrm{n}=19)$. Furthermore, significant positive linear regressions were found between ANP values and both pulmonary wedge pressure $(r=.735$, $P=.0018, \mathrm{n}=15)$ and left atrial chamber dimension $(r=.678, P=.0055, \mathrm{n}=15)$ values but not with right atrial chamber dimension values.

The time course of ANP circulating levels throughout the kinetic study, measured in three typical patients (two patients from group 1 and one patient from group 2) with greatly different ANP levels, was reported in Fig 1⿴. Wide but not systematic fluctuations of ANP levels were observed when compared with basal values (before tracer injection).

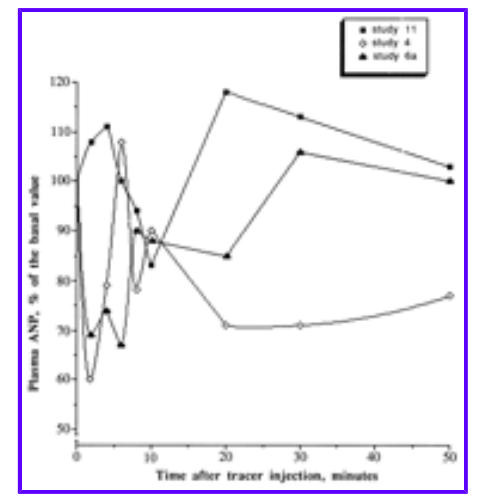

View larger version $(20 \mathrm{~K})$ :

[in this window]

in a new window
Figure 1. Plot shows time course of plasma atrial natriuretic peptide (ANP) concentrations in three patients in whom hormonal levels were assayed in several experimental plasma samples collected throughout the kinetic study by a direct (without extraction) radioimmunoassay method. Values are expressed as percent of the basal values (sample collected before tracer injection).

PRA levels were significantly increased in patients with IDC (patients, $3.191 \pm 3.970 \mathrm{ng} / \mathrm{mL} / \mathrm{h}$; control subjects, 
$0.667 \pm 0.356 ; P=.0463)$ and tended to progressively increase with the clinical severity of the disease even if the mean values were not significantly different between the two groups of patients $(2.009 \pm 1.641 \mathrm{ng} / \mathrm{mL} / \mathrm{h}$ versus $4.373 \pm 5.259 \mathrm{ng} / \mathrm{mL} / \mathrm{h})$. Moreover, significant positive correlations were also found between PRA levels and pulmonary wedge pressure $(r=.610, P=.0157, \mathrm{n}=15)$, left atrial chamber dimension $(r=.527, P=.0437, \mathrm{n}=15)$, and right atrial chamber dimension $(r=.517, P=.0484, \mathrm{n}=15)$ values.

These data, taken as a whole, suggest that activation of both vasoactive hormonal systems increased with progression of clinical severity of the disease and with the deterioration of hemodynamics, even if the residual effects of drugs (for example, the effect of ACE inhibitors on PRA levels) cannot be excluded.

Plasma aldosterone did not significantly differ among the patient groups and control subjects and did not show any correlations with ANP or PRA values, nor with the clinical severity of the disease; this finding may be explained by the opposite effects of ANP and the renin-angiotensin system on aldosterone production and by the action of other important biological factors (including some neurotransmitters and electrolytes) that also can independently affect mineralocorticoid production by the adrenal gland. $\underline{26}$

\section{Results of the Turnover Study}

Six representative, individual disappearance curves obtained in control subjects and in the two groups of patients with IDC, studied at different sodium excretion rates, are reported in Fig 2⿴囗十 In all control subjects and patients, the experimental plasma disappearance curves of $\left[{ }^{125} \mathrm{I}\right] \mathrm{ANP}$ were satisfactorily fitted by a biexponential function.

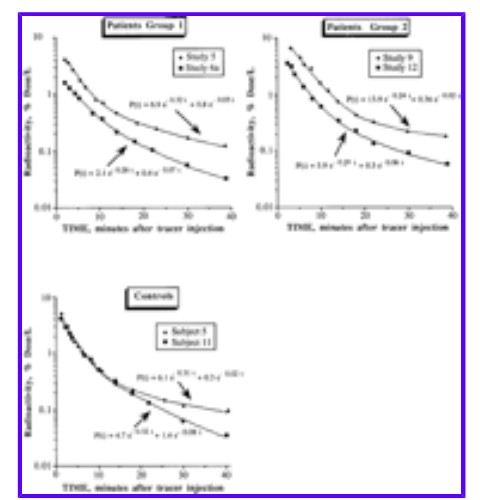

View larger version $(27 \mathrm{~K})$ :

[in this window]

[in a new window]
Figure 2. Representative disappearance curves of labeled atrial natriuretic peptide in normal subjects and in the two groups of patients with idiopathic dilated cardiomyopathy. For each studied group, the kinetic curves of two patients or subjects at different sodium intakes (low and relatively high) are represented. For each disappearance curve, the two exponential fitting functions are also reported, together with the corresponding values for the coefficents and exponents $\left(\mathrm{min}^{-1}\right)$.

The main kinetic parameters calculated from the experimental plasma disappearance curves of $\left[{ }^{125} \mathrm{I}\right] \mathrm{ANP}$ in all control subjects and patients studied are reported in Table $3 \varpi$. The patients with IDC, taken as a whole, showed significantly lower values for TDV (patients, $16.3 \pm 7.2 \mathrm{~L} / \mathrm{m}^{2}$; control subjects, $27.0 \pm 11.7 \mathrm{~L} / \mathrm{m}^{2} ; P=.0048$ ) and MRTB (patients, $7.4 \pm 2.1$ minutes; control subjects, $18.2 \pm 19.2$ minutes; $P=.0240$ ), and higher PR (patients, $280.8 \pm 197.4 \mathrm{ng} / \mathrm{min} / \mathrm{m}^{2}$; control subjects, $\left.130.7 \pm 105.4 \mathrm{ng} / \mathrm{min} / \mathrm{m}^{2} ; P=.0283\right)$ than control subjects.

View this table: Table 3. Main Kinetic Parameters of the Subjects Studied [in this window] [in a new window]

When the patients were divided into two subgroups (Table 3田), patients of group 1 showed higher (ANOVA, $P=.0040)$ ANP MCR values than patients of group $2(P=.0082)$ and control subjects $(P=.0197)$. Patients of group 2 showed significantly lower (ANOVA, $P=.0146)$ IDV values than those of group $1(P=.0276)$ and control 
subjects ( $P=.0469$ ), as well as lower (ANOVA, $P=.0050$ ) TDV values than control subjects $(P=.0051)$. In addition, patients of group 2 showed significantly higher (ANOVA, $P=.0008$ ) ANP PR values than those of group $1(P=.0085)$ and control subjects $(P=.0015)$.

Based on the biexponential shape of the time course of plasma disappearance curves, the body pool of the hormone can be considered a sum of two exchanging spaces: the first one (initial distribution space, IDV) exchanging almost instantaneously with plasma (into which the tracer was injected) and the second one exchanging more slowly with plasma. Patients with IDC showed a progressive reduction in TDV, mainly due to a significant (ANOVA, $P=.0067$ ) contraction of peripheral distribution spaces (PDV calculated as TDV-IDV) (Table 3田). Indeed, in patients of group 1, IDV values were superimposable to those of control subjects (group 1, 11.3 $\pm 4.7 \mathrm{~L} / \mathrm{m}^{2}$; control subjects, $10.7 \pm 3.4 \mathrm{~L} / \mathrm{m}^{2}$ ), and only the PDV tended to be reduced (group $1,8 \pm 3 \mathrm{~L} / \mathrm{m}^{2}$; control subjects, $\left.16 \pm 9 \mathrm{~L} / \mathrm{m}^{2} ; P=.0556\right)$; conversely, in patients of group 2 , both IDV $\left(7 \pm 2 \mathrm{~L} / \mathrm{m}^{2}, P=.0469\right)$ and PDV $\left(6 \pm 5 \mathrm{~L} / \mathrm{m}^{2}, P=.0110\right)$ values were significantly reduced compared with control subjects.

As already found in control subjects, $\underline{22}$ a positive regression between ANP MCR values and the daily excretion of sodium was also observed in the IDC patients of both groups (Fig 3国). Different relations between MCR values and sodium excretion were, however, observed in patients and control subjects (slopes significantly different, $P<.01$; intercepts not significantly different). Indeed, throughout the range of sodium excretion studied, the MCR values of patients of both groups were always higher (approximately doubled) than the values found in control subjects at the corresponding sodium excretions (Fig 3国). This finding can be better appreciated by observing the ratio between ANP MCR values and the corresponding urinary sodium excretions determined in each patient and control subject (Fig 4⿴囗十); a significant difference was found for this ratio between both group $1\left(27.7 \pm 11.4\left[\mathrm{~mL} / \mathrm{min} / \mathrm{m}^{2}\right] /[\mathrm{mmol} / \mathrm{d}]\right)$ and group $2\left(24.2 \pm 8.0\left[\mathrm{~mL} / \mathrm{min} / \mathrm{m}^{2}\right] /[\mathrm{mmol} / \mathrm{d}]\right)$ and control subjects $\left(10.7 \pm 0.9\left[\mathrm{~mL} / \mathrm{min} / \mathrm{m}^{2}\right] /[\mathrm{mmol} / \mathrm{d}]\right)$. These data indicate that in both groups of patients, the same sodium excretion was associated with an approximately doubled removal rate of the hormone compared with control subjects; this suggests that ANP peripheral utilization is less effective in excreting sodium in patients with IDC.

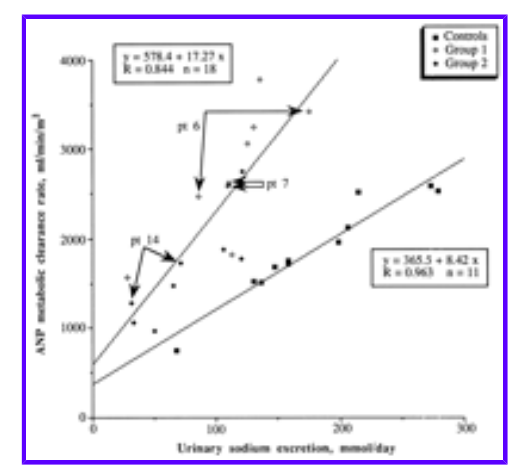

View larger version $(21 \mathrm{~K})$ :

[in this window]

[in a new window]
Figure 3. Linear regressions between daily urinary sodium excretion (mean of all 24-hour urinary collections, $\mathrm{mmol} / \mathrm{d}$ ) and atrial natriuretic peptide (ANP) metabolic clearance rate $\left(\mathrm{mL} / \mathrm{min} / \mathrm{m}^{2}\right)$ values found in control subjects and patients. Arrows indicate values for the three patients studied twice. 


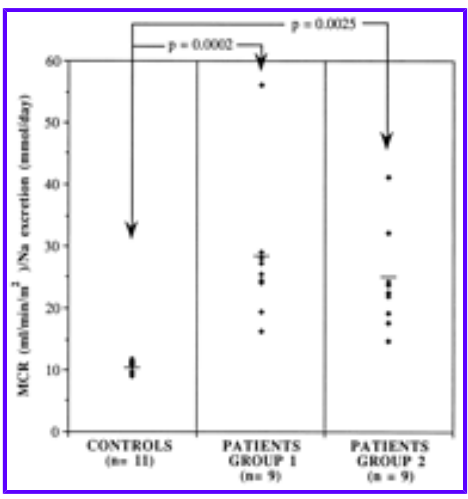

View larger version $(21 \mathrm{~K})$ :

[in this window]

[in a new window
Figure 4. Plot shows ratio of atrial natriuretic peptide metabolic clearance rate $\left(\mathrm{mL} / \mathrm{min} / \mathrm{m}^{2}\right)$ and sodium excretion $(\mathrm{mmol} / \mathrm{d})$ values in the two groups of idiopathic dilated cardiomyopathy patients and in control subjects.

\section{Discussion}

In studies of the possible pathophysiological role of ANP in heart failure, generally only the circulating levels of the hormone have been measured. $\underline{6} \underline{8} \underline{8} \underline{10} \underline{11} \underline{12}$ These studies demonstrated that ANP assay actually represents a useful tool in the follow-up of patients with heart failure. $\frac{27}{-}$ Indeed, our data confirm $\underline{27}$ that ANP levels can be considered a good index of clinical severity of disease (as indicated by the significant difference between ANP levels observed in the two groups of patients) and/or deterioration of hemodynamics (as indicated by the significant correlations with

$\Delta \underline{\text { Top }}$

- Abstract

- Introduction

- Experimental Subjects

- Control Group

$\Delta$ Methods

- Results

- Discussion

References PWP and LACD).

On the other hand, it has been shown that plasma ANP levels exhibit marked variability attributable to pulsatory pattern of secretion. $\underline{28}$ The time course of plasma ANP levels of the three patients (Fig 1⿴) in whom several experimental blood samples collected during the kinetic study were assayed also confirms a marked variability in circulating plasma ANP concentrations in humans at rest, mainly reflecting a very rapid pulsatory pattern of hormone secretion. The fact that plasma levels closely reflect pulsatory pattern of secretion is confirmed by our findings of very rapid decrease of labeled ANP (plasma half-life about 2 minutes for the predominant fast exponential component); this suggests some caution in interpreting isolated plasma values. $\underline{28}$ Furthermore, our findings indicate that isolated ANP levels cannot be considered per se a reliable index of hormonal effect, as suggested by the weak and negative correlation with urinary sodium excretion found in our IDC patients.

An evaluation of the main turnover parameters (such as MCR) might represent a significant improvement in the assessment of the functioning of the overall ANP system as compared with the measurement of ANP circulating levels only. Different items of information can be derived from the evaluation of the renewal and degradation pathways, which require hours or even days for their modulation. Indeed, our tracer method provided

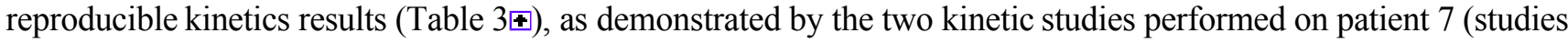
$7 \mathrm{a}$ and $7 \mathrm{~b}$ ) with a 7-day interval at the same sodium intake (Table 2థ).

Some authors $\underline{12} \underline{13} \underline{14} \underline{15} \underline{16} \underline{17} \underline{18} \underline{19} \underline{20} \underline{21}$ have infused pharmacological doses of the hormone to evaluate its biological effects and/or to estimate the main kinetic parameters of ANP in patients with heart failure. However, the infusion of pharmacological doses of the hormone, which per se produces some biological effects, clearly perturbs the steady-state condition, thereby affecting the estimation of turnover parameters. On the contrary, the tracer method used in the present study to evaluate ANP kinetics does not affect the steady-state condition. $\frac{22}{}$ In addition, our kinetic approach, using a bolus injection of the tracer (instead of a constant infusion), makes it possible to calculate additional kinetics parameters (such distribution volumes, mean transit times, and mean residence times), providing more accurate and complete information on ANP kinetics $\underline{22}$ (Table 3田). 
Since there is experimental evidence that ANP is rapidly degraded by lysosomal hydrolases after its binding to the cell surface and subsequent internalization via receptor-mediated endocytosis, $\underline{29} \underline{30}$ it is likely that degradation and biological hormonal effects may be strictly related. Moreover, as the chief function of the hormone is perceived to be an action on the kidney to facilitate the excretion of sodium and water, $\underline{31} \underline{\underline{32}}$ it is conceivable that ANP degradation rate can be related to renal sodium handling. Indeed, we found in a previous study $\underline{22}$ and we now confirm in a larger series of normal subjects a close correlation between sodium excretion and ANP clearance (Fig 3 ๑).

The significant increase in ANP MCR (relative to sodium intake/excretion) observed in patients in the early phase of clinical disease, as compared with normal subjects, indicates the presence of a disturbed mechanism underlying hormone degradation and its biological effects (for example, sodium excretion). In this respect, the different relations between ANP MCR and daily sodium excretion found in patients versus control subjects, that is to say, the fact that an approximately doubled ANP MCR was required in patients to produce the same biological effect (that is, the same sodium excretion over a 24-hour period) as in control subjects (Fig 3田 and Table 3田), can be interpreted as a hormone degradation that is biologically "less effective" in excreting sodium. Indeed, because a reduced biological effect (for example, sodium excretion) is associated with an elevated ANP removal (Fig 4థ), one can suppose that the hormone may be degraded in organs and tissues, such as lung tissue and vascular cells, which are rich in degradative enzymes and receptors and are interposed between the secretion site(s) and the natriuretic target organ (for example, kidney). $\underline{29} \underline{30} \underline{31} \underline{32}$ Note that this type of reduction of biological activity can be detected only by means of tracer kinetic studies under steady-state conditions. Besides peripheral degradation, tissue distribution also was found to be profoundly disturbed (for example, a reduction of exchanges with peripheral target tissues) in patients with IDC, both taken as a whole and when they were subdivided into two subgroups based on the clinical severity of the disease (those with minimal signs and symptoms of disease and minimal activation of neurohormonal vasoactive system and those with more severe symptoms of heart failure)

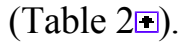

Finally, our findings of a reduced MCR in the presence of a significant increase in ANP PR in patients with severe clinical disease (group 2), when compared with patients at an early stage of clinical disease (group 1), are consistent with the hypothesis of a resistance syndrome to the natriuretic effect of ANP in patients with IDC.

\section{Conclusions}

Our data show that subjects with idiopathic dilated cardiomyopathy, even with only mild hemodynamic abnormalities and little or no symptoms of heart failure, have abnormalities of ANP kinetics. These abnormalities are present even when plasma concentrations of ANP, PRA, and aldosterone may be different from those of control subjects.

\section{Acknowledgments}

This work was partially supported by a grant from the National Research Council (CNR) of Italy. We would like to express our gratitude to Dr Antonio Caselli for suggestions in preparing the manuscript and Roberta Bertolini and K. Galligani for secretarial assistance. Stefano Turchi, Franco Cazzuola, and Scipione Pugliese provided technical assistance, and Marisa Corfini provided dietetic assistance.

\section{$>$ Footnotes}

Reprint requests to G. Iervasi, MD, CNR Institute of Clinical Physiology, Via P, Savi 8, 56100 Pisa, Italy.

Received September 14, 1994; accepted November 13, 1994. 


\section{References}

1. Francis GS, Goldsmith SR, Levine TB, Olivary HT, Cohn JT. The neurohumoral axis in congestive heart failure. Ann Intern Med. 1984;101:370-377. [Medline] [Order article via Infotrieve]

2. Brandt RR, Scott Wright R, Redfield MM, Burnett JC. Atrial natriuretic peptide in heart failure. J Am Coll Cardiol. 1993;22(suppl A):86A-92A.

3. Cody RJ. Neurohormonal influences in the pathogenesis of congestive heart failure. Cardiol Clin. 1989;7:73-86. [Medline] [Order article via Infotrieve]

\begin{tabular}{l} 
A Top \\
A Abstract \\
A Introduction \\
A Experimental Subjects \\
A Control Group \\
Methods \\
- Results \\
- Discussion \\
\hline References
\end{tabular}

4. De Leew PW. Renin-angiotensin-aldosterone system. In: Zipes DP, Rowlands DJ, eds. Progress in Cardiology. Philadelphia: Lea \& Febiger; 1991:101-111.

5. Dietz R, Haass M, Osterziel KJ. Atrial natriuretic factor and arginine vasopressin. In: Zipes DP, Rowlands DJ, eds. Progress in Cardiology. Philadelphia: Lea \& Febiger; 1991:113-133.

6. Raine AEG, Erne P, Burgisser F , Muller FB, Bolli P, Burkart F, Buhler FR. Atrial natriuretic peptide and atrial pressure in patients with congestive heart failure. $N$ Engl J Med. 1986;315:533-537. [Abstract]

7. Burnett JR Jr, Kao KC, Hu DC, Heser DW, Heublein D, Granger JP, Opgenorth J, Reeder GS. Atrial natriuretic peptide elevation in congestive heart failure in the human.

Science. 1986;231:1145-1147. [Abstract/Free Full Text]

8. Bates ER, Shenker Y, Grekin RJ. The relationship between plasma levels of immunoreactive atrial natriuretic hormone and hemodynamic function in man. Circulation. 1986;73:1155-1161. [Abstract/Free Full Text]

9. Rodeheffer RJ, Tanaka I, Imada T, Hollister AS, Robertson D, Inagami T. Atrial pressure and secretion of atrial natriuretic factor into the human central circulation. $J$ Am Coll Cardiol. 1986;8:18-26. [Abstract]

10. Moe GW, Canepa-Anson R, Armstrong PW. Atrial natriuretic factor: pharmacokinetics and cyclic GMP response in relation to biologic effects in severe heart failure. $J$ Cardiovasc

Pharmacol. 1992;19:691-700. [Medline] [Order article via Infotrieve]

11. Gottlieb SS, Kukin ML, Ahern D, Packer M. Prognostic importance of atrial natriuretic peptide in patients with chronic heart failure. J Am Coll Cardiol. 1989;13:1534-1539. [Abstract]

12. Cody RJ, Atlas SA, Laragh JH, Kubo SH, Covit AB, Ryman KS, Shaknovich A, Pondolfino K, Clark M, Camargo MJ. Atrial natriuretic factor in normal subjects and heart failure patients: plasma levels and renal, hormonal and hemodynamic responses to peptide infusion. J Clin Invest. 1986;78:1362-1374. [Medline] [Order article via Infotrieve]

13. Saito Y, Nakao K, Nishimura K, Sugawara A, Okumura K, Obata K, Sonoda R, Ban T, Yasue H, Imura H. Clinical application of atrial natriuretic polypeptide in patients with congestive heart failure: beneficial effects on left ventricular function. Circulation. 1987;76:115-124. [Abstract/Free Full Text]

14. Riegger GAJ, Kromer EP, Kochsiek K. Human atrial natriuretic peptide: plasma levels, hemodynamic, hormonal, and renal effects in patients with severe congestive heart failure. J Cardiovasc Pharmacol. 1986;8:1107-1112. [Medline] [Order article via Infotrieve]

15. Molina CR, Fowler MB, McCrory S, Peterson C, Myers BD, Schroeder JS, Murad F. Hemodynamic, renal and endocrine effects of atrial natriuretic peptide in severe heart failure. $\mathrm{J} \mathrm{Am} \mathrm{Coll} \mathrm{Cardiol.}$ 1988;12:175-186. [Abstract]

16. Fifer MA, Molina CR, Quiroz AC, Giles TD, Hermann HC, De Scheerder IR, Clement DL, Kubo S, Cody RJ, Cohn JN, et al. Hemodynamic and renal effects of atrial natriuretic peptide in congestive heart failure. Am J Cardiol. 1990;65:211-215. [Medline] [Order article via Infotrieve]

17. Moe GW, Canepa-Anson R, Howard RJ, Armstrong PW. Response of atrial natriuretic factor to postural changes in patients with heart failure versus subjects with normal hemodynamics. $J$ Am Coll Cardiol. 1990;16:599-606. [Abstract]

18. Woods RL. Contribution of the kidney to metabolic clearance of atrial natriuretic peptide. Am J Physiol. 1988;255:E934-E941. [Abstract/Free Full Text]

19. Cusson JR, Hamet P, Gutkowska J, Kinchel O, Genest J, Cantin M, Larochelle P. Effects of atrial natriuretic factor on natriuresis and cGMP in patients with essential hypertension. J Hypertens. 1987;5:435-443. [Medline] [Order article via Infotrieve]

20. Nakao K, Sugawara A, Morii N, Sakamoto M, Yamaola T, Itoh H, Shiono S, Saito Y, Nishimura K, Ban T, et al. The pharmacokinetics of alpha-human atrial natriuretic polypeptide in healthy subjects. Eur J Clin Pharmacol. 1986;31:101-103. [Medline] [Order article via Infotrieve]

21. Yandle TGA, Richards MG, Nicholls G, Cuneo R, Espiner EA, Liveset H. Metabolic clearance and plasma half life of alpha-human atrial natriuretic peptide in man. Life Sci. 1986;38:1827-1833. [Medline] [Order article via Infotrieve]

22. Iervasi G, Clerico A, Berti S, Pilo A, Vitek F, Biagini A, Baratto MT, Bianchi R, Donato L. ANP kinetics in normal men: in vivo measurement by a tracer method, and correlation with sodium intake. Am J Physiol. 1993;264:F480-F489. [Abstract/Free Full Text] 
23. Baratto MT, Berti S, Clerico A, Fommei E, Del Chicca MG, Contini C. Atrial natriuretic peptide during different pacing modes in a comparison with hemodynamic changes. PACE Pacing Clin Electrophysiol. 1990;13:432-442. [Medline] [Order article via Infotrieve]

24. Clerico A, Del Chicca MG, Giganti M, Zucchelli GC, Piffanelli A. Evaluation and comparison of the analytical performances of two RIA kits for the assay of atrial natriuretic peptides (ANP). J Nucl Med Allied Sci. 1990;34:81-87. [Medline] [Order article via Infotrieve]

25. Clerico A, Opocher G, Pelizzola D, Panzali F, Andreoni P, Del Chicca MG, Giganti M, Zucchelli GC, Piffanelli A. Evaluation of the analytical performance of RIA methods for measurement of atrial natriuretic peptides (ANP): a multicentre study. J Clin Immunoassay. 1991;14:251-256.

26. Quinn SJ, Williams GH. Regulation of aldosterone secretion. In: James VTH, ed. The Adrenal Gland, ed 2. New York: Raven Press Publishers; 1992:159-189.

27. Benedict CR, Phil D. Neurohumoral aspects of heart failure. Clin Cardiol. 1994;12:9-23.

28. Nugent AM, Onuoha GN, McEneaney DJ, Steele IC, Hunter SJ, Prasanna K, Campbell NPS, Shaw C, Buchanan KD, Nicholls DP. Variable patterns of atrial natriuretic peptide secretion in man. Eur J Clin Invest. 1994;24:267-274. [Medline] [Order article via Infotrieve]

29. Hirata Y, Takata S, Tomita M, Takaichi S. Binding, internalization, and degradation of atrial natriuretic peptide in cultured vascular smooth muscle cells of rat. Biochem Biophys Res Commun. 1985;132:976-984. [Medline] [Order article via Infotrieve]

30. Martin ER, Ballermann BJ. Atrial natriuretic peptide receptors. In: Brenner BM, Stein JH, eds. Atrial Natriuretic Peptides. New York, NY: Churchill Livingstone; 1989:105-135.

31. Ruskoaho H. Atrial natriuretic peptide: synthesis, release, and metabolism. Pharmacol Rev. 1992;44:479-602. [Free Full Text]

32. Turrin M, Gillis CN. Removal of atrial natriuretic peptide by perfused rabbit lungs in situ. Biochem Biophys Res Commun. 1986;140:863-873.

\section{This article has been cited by other articles: (Search Google Scholar for Other Citing Articles)}

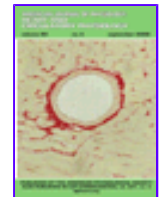

Am. J. Physiol: Heart and Circulatory Physiology

HOME

A. Clerico, F. A. Recchia, C. Passino, and M. Emdin

Cardiac endocrine function is an essential component of the

homeostatic regulation network: physiological and clinical

implications

Am J Physiol Heart Circ Physiol, January 1, 2006; 290(1): H17 - H29.

[Abstract] [Full Text] [PDF]

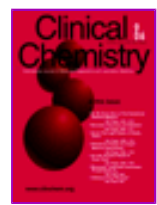

Clinical Chemistry

A. Clerico, M. Emdin, J. P. Goetze, and J. F. Rehfeld

Endocrine Paradox in Heart Failure: Resistance to Biological Effects

of Cardiac Natriuretic Hormones * Drs. Goetze and Rehfeld respond:

Clin. Chem., December 1, 2004; 50(12): 2465 - 2468.

[Full Text] [PDF]

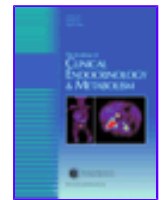

THE JOURNAL OF CLINICAL ENDOCRINOLOGY \& METABOLISM

HOME

G. Iervasi, A. Clerico, A. Pilo, F. Vitek, S. Berti, C. Palmieri, M. Ravani, L. Sabatino, C. Manfredi, M. G. Del Chicca, A. Biagini, and L. Donato

Evidence That Atrial Natriuretic Peptide Tissue Extraction Is Not Changed by Large Increases in Its Plasma Levels Induced by Pacing in Humans

J. Clin. Endocrinol. Metab., March 1, 1997; 82(3): 884 - 888.

[Abstract] [Full Text] 
G. Iervasi, A. Clerico, A. Pilo, L. Sabatino, C. Manfredi, F. Forini, M. G.

Del Chicca, C. Palmieri, M. Ravani, and L. Donato

Atrial Natriuretic Peptide Is Not Degraded by the Lungs in Humans

J. Clin. Endocrinol. Metab., August 1, 1998; 83(8): 2898 - 2906.

[Abstract] [Full Text]

Am. I. Phosiol: Bndocrinology and Metalionliom

HOME

A. Pilo, G. Iervasi, A. Clerico, F. Vitek, S. Berti, C. Palmieri, A. Biagini, and L. Donato

Circulatory model in metabolic studies of rapidly renewed

hormones: application to ANP kinetics

Am J Physiol Endocrinol Metab, March 1, 1998; 274(3): E560 - 572.

[Abstract] [Full Text]

This Article

- Abstract FREE

- Alert me when this article is cited

- Alert me if a correction is posted

Citation Map

Services

- Email this article to a friend

- Similar articles in this journal

- Similar articles in PubMed

- Alert me to new issues of the journal

Download to citation manager

Request Permissions

$$
\text { Google Scholar }
$$

- Articles by Iervasi, G.

- Articles by Donato, $\mathrm{L}$.

- Articles citing this Article

PubMed

PubMed Citation

- Articles by Iervasi, $\mathrm{G}$.

- Articles by Donato, L.

\footnotetext{
HOME HELP FEEDBACK SUBSCRIPTIONS ARCHIVE SEARCH TABLE OF CONTENTS CIRCULATION ART, THRO, VASC BIO ALL AHA JOURNALS CIRCULATION RESEARCH HYPERTENSION STROKE
} 